\title{
Women Entrepreneurship of Bangladesh: A Contextual Study on Beauty Parlor Business of Rangpur Expanse
}

\author{
Md. Julfikar Ali, Md. Masud Rana \\ Department of Management Studies, Begum Rokeya University, Rangpur, Bangladesh \\ Email address: \\ julfikar05.bd@gmail.com (Md. J. Ali), Masud_brur@yahoo.com (Md. M. Rana)
}

To cite this article:

Md. Julfikar Ali, Md. Masud Rana. Women Entrepreneurship of Bangladesh: A Contextual Study on Beauty Parlor Business of Rangpur Expanse. International Journal of Business and Economics Research. Vol. 5, No. 3, 2016, pp. 61-70. doi: 10.11648/j.ijber.20160503.15

Received: April 19, 2016; Accepted: April 28, 2016; Published: May 13, 2016

\begin{abstract}
Women can play imperative role to economies of a country from any derivation of glassy. Bangladesh is a developing country, the women of Bangladesh is deprived and discriminated for many reasons. But it is an optimistic achievement is that they are now levitation their action to empower themselves. By this study it is shown that general status of women entrepreneurship of Bangladesh special deliberation of Rangpur region from the scenarios and the problems of the beauty parlor business of north Bengal. About $96.67 \%$ beauty caring women customer using these services on the other hand most of the beauty parlor is dominated by the women. $75 \%$ beauty parlor is maintained by the sole proprietorship. Moreover the women of this region is very aware of their self-reliant matter besides facing some social problems, ethical problem, funding problem, women business recognition problem, accommodation setting problem lacking of overall assistant-ship of the government specially focusing on the beauty parlor business expansion that spectacles as one of the best portion of women entrepreneurship pictures of Bangladesh. To ascertain the gist figures it is steered open-ended question at the outset and secondary data as per the requirements of descriptive analysis of the study. The study acclaimed a model (Sbs-model) that developed by the author for the enactment of business corresponding beauty parlor business in Bangladesh for several concerns that may relax to the women who are involved of such business and who wants to. At all this study cognize the subjects of beauty parlor business of Bangladesh of the north Bengal about the problems and prospects issues to empower the women and intensifying women entrepreneurship of Bangladesh.
\end{abstract}

Keywords: Women Entrepreneurship, Sbs-model, Optimistic Achievement

\section{Introduction}

Women's pecuniary enabling is an inescapable part of economic expansion sermon in any enlargement undertaking of a country. Women can play important character in involving with different triggering activities. By the involving of different enlargement activities it makes a position on the space of a gallery of development, one of the site is women entrepreneurship. Beauty parlor is very potential business for the eye of developing nation. A potential important determinant of the possibility of a business is the nature of public attitude towards that. A beauty parlor today is widely used everywhere for its mass services, high demand and low cost. It plays a vital role in modern life, especially in the adolescents mind. Most of the girls today are habituated to go to the parlor today boys also try to keep fit the beauty world and taking different types of services from beauty parlor. At the early stages of the increasing of this business, a few attractions were there towards establishing a beauty parlor. Using different types of technology for providing the caring of beauty and keep the fitness Longley and taking some special tips of healthcare and introducing the new way of changing fashion in the dynamic worlds. Generally In greater portion of western culture and Indian cultures it has been made a spot in the mind Bengali because heavy portion of Bangladesh familiarized to ensuing those culture from various comportment by this streaming culture it is trying to make a of business on concentrating this practices. Bangladesh is the country, the people are not abundantly bright to lead the life to outing with living standard but some noticeable people are generally trying to proceeds distinctive attention for their life style. Like Dhaka, Chittagong region, Sylhet region, Rangpur region is the one of crucial part of Bangladesh there it is 
escalating the small business from the corner level of underprivileged area. It is conspicuous thing is that the beauty parlor businesses one of leading business in Rangpur Region on the pipeline of women empowerment .The world today is becoming more ornate than that it was. Therefore the people are seemed to be more attached with the desire to ornate themselves. There is always a firsthand custom towards which the intension of the people is gone through. A need to keep a pace with the changing fashion, the necessity of beauty parlor emerged. The people of Rangpur region is not beyond the grid of modernization. The people here are also fond of enjoying some trendy of beautification services provided by the beauty parlor that's why it is established many beauty parlor. Not only the puberties but also aged people are seemed to go to the beauty parlor in a regular basis. Beauty parlor as a business is getting magnetism day by day. The amount of investment in starting a beauty parlor business is less than other businesses. And maybe this is a reason of being popularized of this business. As there are no hard administrative and legal bindings in establishing a beauty parlor business, someone can easily be attracted towards this business. A beauty parlor there is a need of specialized and skilled beauticians to whom the success and progress of that business depends upon. Though there is no shortage of people who wants a job, there is a severe shortage in the number of skilled beauticians. But the numbers of beauty parlors are increasing day by day for its increasing customers. More people are seemed to be happy in investing their capital and time on this particular business. Most of the beauty parlor is initiated a single ownership type. Women entrepreneurs have a special role to play in creating empowerment and establishing entitlement at all levels of socioeconomic development (Choudhury, Hossain \& Solaiman, 2008) [1]

\section{Theoretical Framework of the Study}

\section{Entrepreneurship:}

Entrepreneurship is the process of designing, launching, and running a new business, i.e. a startup company offering a product, process or service. Accrding to AK Yetisen, LR Volpatti, AF Coskun, S Cho, E Kamrani, H Butt, A Khademhosseini and SH Yun (2015) [2]

Entrepreneurship is the willingness to take risks and develop, organize and manage a business venture in a competitive global marketplace that is constantly evolving according to pinchot.edu [3]

Entrepreneur:

The entrepreneur is "a person who organizes and manages any enterprise, especially a business, usually with considerable initiative and risk." by dictionary.com [4]

"An entrepreneur is someone who can take any idea, whether it be a product and/or service, and have the skill set, will and courage to take extreme risk to do whatever it takes to turn that concept into reality and not only bring it to market, but make it a viable product and/or service that people want or need," Gottlieb said published by businessdaily.com [5]

\section{Women Entrepreneurship:}

Women entrepreneur may be defined as a woman or group of women who initiate, organize, and run a business enterprise. In terms of Schumpeterian concept of innovative entrepreneurs, women who innovate, imitate or adopt a business activity are called "women entrepreneurs" by yourarticlelibrary [6]

Beauty Parlor:

A beauty salon or beauty parlor (beauty parlour) (or sometimes beauty shop) is an establishment dealing with cosmetic treatments for men and women by oxforddictionaries [7]

A place where your hair, face, and body can be given special treatments to improve their appearance by dictionary. cambridge. [8]

Marketing Plan:

A marketing plan has a formal structure, but can be used as a formal or informal document which makes it very flexible. It contains some historical data, future predictions, and methods or strategies to achieve the marketing objectives. Marketing plans start with the identification of customer needs through a market research and how the business can satisfy these needs while generating an acceptable level of return according to BusinessDictionary.com [9]

\section{Literature Review}

The reflection of this portion is to deliver a perceptive review of the past research all of it associated with the contemporary study, Encircled by the researches completed the subsequent are mentionable:

Woman entrepreneurship is the fundamental issue "The emergence of women entrepreneurs in a society depends mainly on economic, social, religious, cultural and psychological factors" (Habib et. al., 2005) [10]

Women entrepreneurs have to encountered different types of obstacles in starting and running a business which includes lack of confidence, funding, access to business networks, family hostility, and culture of masculine advantage and challenges of ethnicity (Gill \& Ganesh, 2007) [11]

Women entrepreneurship development is a challenging phenomenon in Bangladesh as women are lagged behind socially and economically (Haque \& Itohara, 2009) [12]

Most challenging aspects of being in beauty parlor profession was getting social acceptance and respectability, since this is a profession quite different from being a doctor, or banker or even the traditional and conventional professions associated with women. In considering the social status, many of them informed that the impediments came from parents who did not like them to enter into business. (MIDAS, 2009). [13]

Women entrepreneurs of Bangladesh have been transmuting their small individual house-based business activities into a new business venture or enterprise for the last three decades mostly from the family backup rather than institutional support, and they evidenced that they have a 
fabulous potential in empowering women and transforming society. (Dhaka courier, 2010) [14]

This is not surprising for until recently females were confined to private and domestic roles. But the role of entrepreneur does not conform to the traditional roles that females are expected to play in society. These issues, and others, may result in more family conflicts for females than their husbands (World Bank, 2012) [15]

Equivalent many forward-thinking and emerging countries the economic empowerment of women is supposed to work as a catalyst for economic progression and growth of Bangladesh. Social attitudes still characterize entrepreneurship as a male endeavor, and discrimination discourages many women from entering private business (Shah, 2013) [16]

In adding, ensuring access to finance is the most important prerequisite that an entrepreneur must have to operate a beauty salon business. Unfortunately, for women entrepreneurs it is not that easy to avail loan facility from banks and financial institutions, since most of them face problems in providing collateral for security purpose and another critical problem is having trade license/registration because bank do not provide loans without trade license (IDLC, 2014). [17]

Aforesaid study mostly impressed the study of women entrepreneurship of different sectors by this study it is elucidated on the background of beauty parlor business at regional concentration of Bangladesh about the diagnoses and difficulties belongings at altered themes.

\section{Objectives}

The objectives of the study are as follows:

- To designate the present status of Beauty parlor business in Bangladesh women entrepreneurship prospective.

- To identify the contemporary status of beauty parlor business of North Bengal.

- To find the prospects and problems from the contextual scenario of Beauty Parlor business of north Bengal.

- To acclaim solution from the overall sagacity.

\section{Methodology}

This study is descriptive in nature. Data collection has been conducted through direct opened ended questionnaire, taking measurement the respondents of some beauty parlor of north Bengal.

Sampling

For sampling there, we have taken 15 samples with since the different location of Northern region of Bangladesh. To collect data of various pertinent issues of the study direct asking questions of different beauty parlors contemplate. This is the descriptive type study it's the way for sampling data.

Cradles of data

The study is quantitative and mostly qualitative modus. It is based on initially on primary data that have been collected from different beauty parlors in northern area with ranging location. But secondary data have been used in the study for the exploring different information in several grounds of Bangladesh and global consistent issue. The primary data have been collected through setting questionnaire and direct asking of different issues to the beauty parlor authorities. The secondary data have been collected from the publications of newspaper news, Articles and websites, journal, websites, magazine.

Scrutiny of data

The Collected data have been analyzed concluding some common statistical tools and techniques such as average, percentage, pie chart table are used for representing the chronicles.

\section{Significance of the Study}

Economic development is necessary to ensure the overall development of nay country. For that case there need equal participation of male and female both. Bangladesh is economically raising country in the world. This country is very constructive for several reasons especially for the girls or women as a result it is hampering the integrated development at all. But by the demanding situation and the $21^{\text {st }}$ century of advancement it is not have a bit of time to lag behind why not the girls of Bangladesh is now caring to independent. As that case it is a high level of scenario is the women entrepreneurship of Bangladesh is observing. As a developing country it is far reaching question is that to bring everyone in a space to fulfill, it is one of stake to meet that shortcomings. It stated that by this study it can possible to find the general aspects of Women entrepreneurship in Bangladesh at the context of beauty parlor business. Actually, this study covers northern area of Bangladesh with including the overall perception with keeping in head to cognize importance of women entrepreneurship and the problem to solve at pragmatic sense. At the means of developing and creating the opportunity to work thousands of men and women from aggregate development focusing on improving status of Bangladesh this study can give some places to think about the beauty parlor business of Bangladesh at the portion of women entrepreneurship development of equal chipping in development of Bangladesh.

\section{Confines of the Study}

It is descriptive in nature, it is composed with sampling from the set of beauty parlor in Northern region of Bangladesh (primary data) and it is collected secondary data from different articles national and international publication, websites, different organizations and, and some persons who have the knowledge about the beauty parlor in Bangladesh. For collecting the data and making the study we have some limitations, we can summarize by following.

- It is expected a large number of response from the 
respondent but questionnaire answer were just enough the purposes though not adequate.

- Limited coverage of the study did not allow to use certain statistical tools

However, while using and interpreting the result of this study, one should keep the stated limitations in mind.

\section{Discussion}

\subsection{At the Overall Angle}

The definite figure of population in Bangladesh is a dubious character. However it is not at altogether controversial that Bangladesh is one of the overpopulated countries of the world. The growing inclination approximately population creates it entirely moreover strong that are flattering the most precariously compactly populous nation momentarily, if the rate of intensification is not upturned. Each year two million knowledge or educated fledgling men and women are coming to the job arcade. It is approximately dreadful to enthrall this dynamic workforce in the prevailing job souk either in public or in private sector. Better business opportunity can give relax for several reasons to work differently. It is termed that entrepreneurship development of Bangladesh is now a good pictures that helps to diminish the pressure on job market. Women entrepreneurship will be the great way to diminish the pressure at overall work opportunity as per the proportional matter of development to economies the country. Beauty parlor is a profitable business for a female, It will cost Taka 0.1-0.2 million as initial investments and there is a growing market for its services in any town in Bangladesh (The Financial Express, Bangladesh, 2011). it is the process of women empowerment that range on the women entrepreneurship .Entrepreneurship obliges as the reagent in the progression of industrial development and economic tumor. Women entrepreneurs can piece a vital role in contending rural dearth. The arrival and enlargement of women entrepreneurship principally be subject to the subsidiary circumstances of miscellaneous stimuli such as financial, societal, racial, and spiritual. Government and private region involvements have usually enhanced profits creating deeds of females both in the town and pastoral areas with women entrepreneurship advance. By this way to support the facilities, the procedures, and the stratagems advantage to transformation the picture of Bangladesh expressly for the women who wants to encourage herself to breaks the barriers wants to work out of home, wants to be more self-reliant Chamber-of-commerce of Bangladesh data from 2000 signposts that only $8.3 \%$ of the self-employed population of Bangladesh was women. The condition was better-quality in town areas where $15.4 \%$ of the selfemployed were female. The proportion for pastoral areas was only $7.4 \%$. Less than $10 \%$ of all business entrepreneurs in Bangladesh were women. on the behalf of SME by Micro Industries Development Assistance and Services] (MIDAS), 2009] a study publicized some evidence, $87.9 \%$ of woman entrepreneurs in Bangladesh -writhed from a deficiency of capital, $21.3 \%$ did not have decent marketing chances, $20.4 \%$ wished they had better access to raw provisions, $14.2 \%$ lacked skilled workers, $9 \%$ did not have any prior business experience, $8.7 \%$ were not trained themselves and $2.5 \%$ struggled with proper interpretations care. With the expansion of women entrepreneurship by the global focusing, it is looked-for sufficient capital with the requirements human resources for providing the superior services to the customer. In 2003 to now employees' expansion is increasing preferring the position in the expansion level of business. Although in past of the parlor business were maintained with a few number of customer But it is increasing at highly. Customer is the king of market. Most of the people think that beautification is one of the components for exhibiting the world. Getting the global response, view of Indian \& western culture \& growing the area of promotional tools. Now customers are more careful about the beautification. As a result, Beauty parlor business is increasing. In 2003, 2004, 2005 most of the people are involved with the number of services like haircut, facial etc. But it is noticeable is that people are more aware to show the world with full of scenery beautification. The Beauty parlor business has become popular to the people who want to start a small business with small capital to earn more without any risk. So, the number of beauty parlor is increasing. As a result, the competition among them is very acute. The businessman use updates technologies which is expensive. The beauty parlors that use modern products $\&$ technologies are in the better position than the beauty parlors that don't use modern products \& technologies. In the earlier, the customer was not careful about their health \&beauty as the comparison manner of now. But nowadays customers are changing their views and attitude greatly. So, the owners of the beauty parlors are to purchase foreign products to satisfy the appearing customer. The beauty parlors who don't use foreign products cannot survive in this business. In the past, this business was not considered as a profitable earning source and make more self-reliant of women for the entrepreneurship business but it has been possible to expand rapidly due to quick collective variation. The number of beauty parlors is increasing due to the change of ideas \& concept of entrepreneurs. The entrepreneurs can easily start this business with small capital without high risk \& can maintain their families beside this business. This business has also become profitable due to the number of customers. This is why; the number of entrepreneurs in this business is increasing day by day specially women to become more self-reliant. The Beauty parlor business has been changed due to the radical change of technologies. Technologies have become essential factor in beauty parlor business to modernize this business. Technologies help the beauty parlor business in providing better service to the customer. So, the beauty parlors are increasing the use of technologies to satisfy their customers. Increasing training facilities drive the entrepreneurs to make more elegant type of business. The increasing number of beauty parlors on the consistent manner of this it is need 
competent employees. To make the employees qualified, training facilities should be available. The training center provides training facilities to the employees who are interested of this ground. The number of training center is increasing due to a number of respondents who wants to work in the beauty parlor business but at the locational distinction many persons depriving from getting the require training facilities. Increasing consultancy based services is one of the exceptional scenes of beauty parlor business in the worldwide. The activities of beauty parlors are becoming consultancy based services and it is becoming more popular now. They give pertinent suggestions to the customers how to keep their health, skin \& beauty fit. They are undying the customers that which product should be used to keep their skin fit. So, the beauty parlor business is becoming consultancy based day by day. People in different occasions are interested to embellish themselves. Particularly, in the wedding ceremony, it turns out to be essential to make up the bride \& bridegroom. In the social occasions, the beauty parlor s provides package services at high rate. People are very much aware of the special occasions for that case the package services of the beauty parlors are increasing day by day. They are very much profound and loving about to care the beautification. Who has little Affordability enthusiasms to nearby beauty parlor for their embellishment? Among them who are wealthy, they go to some renowned beauty shops, which are situated in dissimilar location. Some of the beauty aware women go a Long way to get the want and proffer beauty shops. Salon industry in Bangladesh Country has high concentration on rivalry, customers also have high trading power Though threat of substitutes \& barraging supremacy of suppliers are stumpy; but the threat of new entrants are sensible. As Bangladesh is a developing country, every means of investment could be encouraged for accumulating the capital. Therefore, beauty parlor as a business could not be neglected as potion the integrated deliberation. Moreover, it should be encouraged as the number of parlor going people is increasing day by day. There found verities of services provided by the beauty parlors of Bangladesh but there are lacks of modern instruments sophistication modus of services, the price of the equipment is high for several concerns. If it is possible to make ensure the modern instruments and beauty materials at lower price the Entrepreneurs will be more encouraged in establishing the beauty parlor business. Efficient beauticians are the prerequisites for the success of a beauty parlor Business. Therefore, skilled and experienced beauticians are to be formed. For that Purpose, adequate training facilities should be provided. Recently there are severe shortage is found regarding the training facilities for the interested people.

\subsection{At the Framework of Rangpur Region}

Rangpur Division is a place where different level people are lived. Though there are very few large industries here, a lot of people are involved with business activities. But most of the businesses are sole proprietorship. Among these sole proprietorship businesses beauty parlor is getting an interest of the people. The beauty parlor in Rangpur region we have found most of beauty parlors here are owned by a single owner. Among this parlor we have found that about $96 \%$ parlors are woman oriented. And the services are also provided by the women. Most of the beauticians found are aboriginal people. It is maximum involvement; minimum expectation and physical fitness make them attached with this job. While doing the study it is originated that most of the beauty products used in the beautification work came from the foreign countries. And that's why the services provided by these parlors are very expensive. Due to some homegrown problems there is some insufficiency in the actualities of services provided by the beauty parlors in Rangpur Region. The beauticians of Rangpur said that though there are limited numbers of fixed customers here, the parlor became teeming throughout occurrences like Eid, Puja, and Marriage etc. As beauty parlor business is a services oriented business, which gives distinct categories from other, its specialized by the local demand of customers morally for the featuring the business. The beauty parlor businesses may be various types. In Rangpur expanse, most of the beauty parlor business is distinct oriented, which creates the single services and operate to the customer. Most the worker are involving in beauty parlor business, they are ethnic. Unskilled employees is the nocked thing, there is not enough training facilities only some of person took a short training from different institution like It Vision ,Thi, Persona etc., but it is not enough . Employees are appointed on the basis of contract. And there not plenty of training fields in the organization boundary. Most of the beauty parlor of the Rangpur Region use foreign cosmetics; they prefer it for the demanding anticipation of customer. There use mostly Indian products. (Gurniar, Square, Sumon Sarma, Momotaz Herbal etc.) Focus highly on teenage, the teenage group of customer is highly addicted to the beauty parlor. They come for style and aesthetic expansion. This is not wholly profession but it's one type of business for providing services. Employees are appointed based on contractual basis. That means there prefer to appoint hour per day, weekly, monthly, quarterly, yearly etc. Using Now a days every beauty parlor trying to use the advanced technology which gives the moderate and fast facilities to their activities - such as update spare, machine, cosmetics etc. up-to-date technology use by beauty parlor for giving popularity. Hair steam, face steam etc. Political environment affects beauty parlor business. It is the municipality area and one of vital political issues includes here political unrest, strike and the total political situation always impacts the business continuation like others small business types. Government has fewer interfaces on of beauty parlor as small business like the international scenario of women entrepreneurship. This business is very popular to the teenage people by and by. Who are very conscious about their aesthetic beauty? This beauty popular is given various qualitative services with very low cost. In addition, it serves various activities through foreign cosmetics, which is adaptable to our culture uses various update technology 
update information about, aesthetic \& other soon. It is seen the improving area of beauty parlor business for several sectors of north Bengal, Services area, Technology and Advancement, providing information to the right person, expanding the investing level, Employment opportunities, Training Facilities, New way/path of Business, Consultancy with services, Govt. Influences etc. Every business tries to give their best effort to serve the customer. The beauty parlor business is not outside them. It provides always better services for the customer. For using various update information technology \& various offer services are expanded. As a result the customer is coming in frequently. In 2004 the customer of beauty parlor is only $25 \%$ of total population but in 2003 the customer of beauty parlor are increased by $65 \%$ of total population. A large amount of advanced technology is used in almost every beauty parlor in Rangpur Region. Technology advancement are massager machine, hair steam, face steamed. The technological advancement is expanding the beauty parlor arrears. At present the available update information are easy reached to the right person by using internet services. As a result, the customers who are conscious about their aesthetic beauty are getting update news \& change them easily. For example, it is placid numerous information from the Bibiyana beauty parlor, persona beauty parlor, IT vision beauty parlor etc. For this way any information are easily provided to the right person. In earlier period the investment level of beauty parlor way very low. But at present the investment level is increasing day by day. The capital formulation is easily collected \& the entrepreneur is very interested to invest in beauty parlor business. In addition various financial assisting corporations give various finance facilities to this sector. The investment level is mounting day by day $\&$ it is very popular irony all the business persons. Employees are the main resources of the every organization. As beauty parlor is a service-oriented business, it must be needed employees. Most of the beauty parlor in Rangpur Region is jumble-sale personnel. As a result the employment opportunities are easily done. These employees are appointed on basis of contractual perspective. Training is very needed to make skilled employees. So beauty parlor business gives various training facilities for their employees. In 2004 the training facilities at beauty parlor was very low at $10 \%$ but in 2013 this training facilities are expanding at $50 \%$. There are various training institutes or center where gives various training facilities to make a efficiency person such as Persona, Bibiyana, IT vision, Living Star Institute, Apur Guar Cooking center etc. Parlor business is new form of business. In earlier period this business was not familiar to society \& society believed that this business was not relevant to their religion. But at present this opinion are proved at wrong. As a result, people are encouraged to the beauty parlor business \& they think positive about beauty parlor business. To sustain in competitive position every business must be provided at better services. The beauty must be provided at given their better services by through their consultants. These consultants are very needed to justify the proper use of beauty parlor cosmetic at present consultants are very popular in beauty parlor business. Govt. cooperation is very much needed for expanding any business why not the beauty parlor business. Now a days Govt. gives various facilities such as providing govt. approved certification, loan facilities, trade license facilities, Award system etc. For this ways the areas of beauty parlor are expanding day by day. In Rangpur Region beauty parlor is made up in various locations. It generates the nice marketing opportunity where no competition is fetching highly. Most of the beauty parlor gives their best services in a number of angles. Beauty parlor business is expanding in Rangpur region. These services are popularized in every Centre. But it has faces various problem which exhausts its promotion. The problems of beauty parlor in Rangpur are termed: severe competition is seen in every business sector. Beauty parlor is not out of this competition .To withstand its particular position, it appearances various competitive site. Sometimes this competition creates the risky position of beauty parlor which exhausts the beauty parlor services. Tax implication is the main obstacle for expanding beauty parlor. In beauty parlor govt. impose large tax which creates the complex situation of beauty parlor. For complex tax implication, the earning profit of beauty parlor business less. As a result, most of the owner of beauty parlor is not interested to establish beauty parlor. Most of the beauty parlor in Rangpur Region is established on the basis of local customer. Local customer have limited demand here no information is exchanging in various regional or geographical areas. As a result, the owner of the beauty parlor does not understand the exact customer supply $\&$ demand. Labor turnover is the indispensible hindrance for expanding beauty parlor. For labor turnover, skilled employees are not find out or specified. As a result, these create a shortage of skilled manpower. In addition, for labor turnover, new employees are recruited by various costing procedures of employment. It is thinkable to encourage the women to involve in the small type business. But our society, our culture is not enough capacity to make it full free from the social backwardness. In the time of stabilizing the entrepreneur basically women in rural areas face abundant social harassment. Training facilities are essential for creating skilled employees'. Without training an employees may not be skilled or efficient. But in Rangpur region, there are not available training institutions for providing training facilities as per the requirements. Till now beauty parlor has not high level of social acceptance in Bangladesh (especially in North Bengal).So social ignorance is hampered its progress so to say the attitude towards the women who are interested to work as women entrepreneurship into this business. The formation of beauty parlor is based on mostly self -investment. But the organizational assistance is essential for expanding beauty parlor activities.

As a result, the organization is not able to come in forward $\&$ is not able to change with update technology \& information. For establishing a beauty parlor, various complex formalities are maintained by the owner .A long time is spent to get a trade license \& trade mark to start a 
beauty parlor business. For the lack of proper lodging facilities, various beauty parlors are established in various places. As a result, there is no co-ordination among this beauty parlor in same activities. Promotional activities are very important to expand beauty parlor business. But in Rangpur region, there is less chance to perform promotional activities. The employees are not contact with a long period. As a result, labor turnover, Employees dissatisfaction is increasing. A consultant is very important in every beauty parlor business .But it is expensive to keep a consultant .So most of the beauty parlor owner avoid this matter. The people of Rangpur region are very poor. So their investment savings are very less. As a result, the capital accumulation is not expanded in various perspectives. People have poor income, but more expense in beauty sector. Hence, capital accumulation problem exists.

\section{Summary and Findings}

It is a type of business there makes the women more enabling assistant the integrated development of a country, for that sense the women of Bangladesh doing so. Seen lot of limitation for expanding the business besides this it is the one of better cities like Dhaka, Sylhet, Chittagong and some of others. From a local newspaper (The Daily Rangpur Chitra) reported in 2010 in the Rangpur region here have about 134 beauty parlor are exist here, It only possible meeting the demand of customer expanding the small business and the responding the international business expansion of beauty parlor like India and the some western parts. Internationally there heavily chance for the women empowerment by the small business. This is not far away to get the improvement periphery at international evaluation. The enthralling a little bit of amount in small business makes them a self-reliant person so to say the women of our society give the envelopment of economic and social development. From the depth investigation with principal and sub-ordinate data, it is illustrated the bird's eye view of services nature about $96.67 \%$ female or women are taking services from the beauty parlor and rest of them $3.33 \%$ are men, $75 \%$ of the beauty parlor owner is established by the sole owner and also running by the sole type business and $25 \%$ is established as the partnership type of business
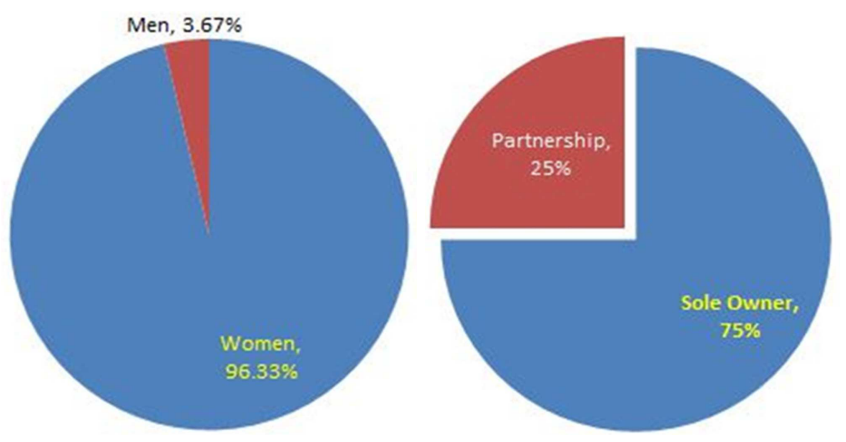

Figure 1. Customer nature and Ownership kind.
After completing a depth investigation it is found a lot of evidence vis-à-vis of beauty parlor business. It is thru a list of major outcome:

- Sole proprietorship ownership mostly.

- Most of the worker of beauty parlor are ethnic group(tribal)

- Most of the customer range is 21-35 years

- They feel intense competition for providing the services at local based interface

- They try to provide services with meeting the global demand of beautification

- Customer, employees increase comparatively preceding.

- Services types are diversified

- Limitation of expansion level basically funding, installment loan, Moral matter ofm attitude towards the women in Bangladesh

- Using new technology with customer outlooks.

- Women Entrepreneurs increase with the demanding situation of Bangladesh

- Social backwardness exists from the acceptance side by side others business.

- Use foreign types of cosmetics and ingredients

- Less response of branding the categories of services

- Highly limitations of training facilities

\section{Recommendations and Conclusion}

It is suggesting that from the overall intellect of the problems and prospects of the beauty parlor business, there need to give assisting entrepreneur development program. Providing small business logistics support. More training facilities requires for the initiative person for regional progress of Rangpur region. Financial drives need to more adapting the growing business to empower the women of the Bangladesh. Although Bangladesh Women Chamber of Commerce and Industry (BWCCI)) is working on the supportive issues of such type of business besides that there needs more government intervention to caliber this business after all by the integrating style of the it should give focus the people to bring up in this services with eliminating the social, backwardness of the women and ensuring the women entrepreneurship development actions at integrated manner. It is required to emphasize to make brand with quality services and how to retain the customer with looking up the sorting of services frontier. It is portentous that for the inclusive ailment of Bangladesh of the beauty parlor business, small business settlement (Sbs) model of business settlement can give better result to go beyond the highly level of business expansion of women entrepreneurship of Bangladesh so to around Regional bases business.

A small business style, it is encompassing a lot of standings for making it accomplishment. Generally, the owner of small business at first he or she when want to start business there following thing works as vitally for the longterm realization.

Major findings: 


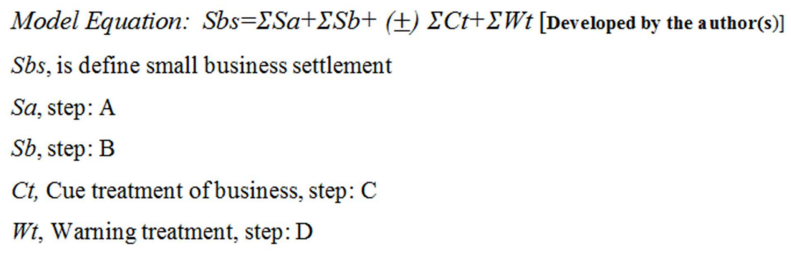

Figure 2. Small Business Settlement (Sbs) Model.

Step-A

Phase-1

Cunning money need to run,

Starting a business must need money most entrepreneurs don't turn profit for the first one or two year. There what to consider, that is the questions, some considerable facts are there following

- Funding

- Regulate monthly expenses

- Determine saving statement

- Make operating budget firstly: monthly basis will be better.

- Determine the rent expenses, training expense, suppliers and emergency fund issue.

- Charges of services, budget and break even should be considered, services criteria fixation, specialty fixation.

- Estimating the charge and customer expectation scenario basis

- Price point consideration should fair and affordable.

- Price should be comparable range with the others

- Funding source and estimate profitable plan of arena basis.

Phase-2

Articulating the legitimate issue,

- Acquire a business license. All businesses in Bangladesh need to perform the formalities issues, to start a business the making ensure the trade license with paying the delineate charge.

- Indispensable be licensed or be approved by the regarding authorities it may some of institutions of training providing organization of the government or others.

Phase-3

Suitable Place of business,

If suitable place is not enough to manage it is tough to mounting the business Locational support helps to diversify the business and provide to make stable situation for continuation.

- Public gathering, high-traffic area. Alongside street and safety area isolate the political unrest area and there may concern the sum of organization something like the school, College University, shopping mall, etc.

- Accessibility is essay there must concern for selecting the location. If parking is an annoyance and traffic is thick on the way to the business, people might not cogitate it worth the exertion

Phase-4

\section{Hiring and accomplishing the training,}

- It is a responsibility as the Small business owner to ensure that the personnel are effectively trained and recognize each process obtainable.

- Experience may give personnel the expertise to concentrate treatment, but, without proper training, she/he would be unaware of the qualities and failings of processes.

- Have a short but clear small business procedures guide in place as soon as can, and give each employee a contract when they start.

Step-B

Phase-1

Clean and anodyne atmosphere,

- Purity is particularly imperative element that can draw clients in again and again. Be certain there towels, foot baths, and supplementary apparatus's are eroded, clean and odor-free.

- Keep tools sharp and current.

- Create the atmosphere relaxing. Play lenient music, use gentle lighting and keep loud chatter between employees at a minimum level.

Phase-2

Eclectic range of services (discretionary),

Many customers desire to have their hair, nails and face done in one place, instead of going to dissimilar spaces. While there can specify in one foremost area (e.g. hair), giving the clients the suitability of a one-stop beauty shop can set business apart from the contestants.

Phase-3

\section{Clients contented,}

It is vital that the business generate and uphold the desirable reputation as a quality hair and Parlor operation, so that the clients keep returning for conservation. Try to give them the best possible experience each time, to make them feel appreciated. A Parlor's finest marketing implement is word-of-mouth. If a customer is pleased with the consequences, he or she will come back to the Parlor; after all, it's a question of trust. Satisfied clients can then assistance pushes the business to their networks, family, and colleagues etc.

Step-C:

\section{Cue-treatment $(C t)$}

Be judicious about time off and take time to complete in lieu give and take system. Set up the salary system and leave system so that workers get waged on time and up to date, and can plaid their time off prerogatives. This is a beauty business; it anticipated to guise superlative! Have the dealings physical what expect as a minimum in grooming for all workers and customary a respectable illustration physically. There also contemplate social value, customer value, social acceptance, customer demand, national interpretation, political opinion., Business swell level of that country, international level of demand of that business, raw material balancing, overall that my include god or bad thing for the initial settlement of business. It is the component of making business success after finishing the above two steps 
of business. These consequences affect harmfully and positively of the business, so imperatively have to work with keeping in head.

Step: D Warning-treatment $(W t)$

To be aware of the liabilities that business can be subjected to because of coincidences and inferior actions there may think about the parlor business. Check with the business on policies that can protect and business from obligation and complaints that may rise from customer criticisms.

It is acclaimed that for the overall sense of the beauty parlor business in Bangladesh by applying this model of the regarding sector it is not so far away to male more selfreliant from diverse causes. A comprehensive action taken by the by the mostly women and men take it as challenges. This not far-flung to dash the level of advance living standard of the detach arena from deprive of different amenities for building sweeping of economy vicissitudes through beauty Parlor business a coincidental of participation of gender.

\section{Conclusion}

No matter how was the woman of Bangladesh but matter is how they are involving now, optimistically Bangladeshi women are now on that trail to triumph the self-reliant and making themselves free of social encumbrances at economies point. "The beauty salon industry is worth around BDT 10 billion and it is growing each day. The sector has been contributing to the economy of the country by employment and revenue generation (IDLC, 2014) [18]. Moreover, women entrepreneurship helps to the women to think about as a profession like others. Entrepreneurship has become an important profession among the women of Bangladesh today at various levels of the society, both in the urban and the rural areas. The reason for the interest varies according to the different classes of the society (Storey, 2008) [19]. it is recognized that highly is that assisting the overall development of Bangladesh as related to GDP. As the historical evidence it is the good sign of any country for ensuring equivalent development. Entrepreneurship is recognized as the engine of growth in economies worldwide. Over the past 20 years female owned businesses grew dramatically in number, revenues and employment. For example, in Norway and Canada nearly 60-65 per cent of the new businesses were started by females (Broehl, 1982 [20]; Comper, 1991 [21]; Gatewood, 2003 [22]). North Bengal of Bangladesh is one of the important portions at economic concern for that if it is possible to eliminate the problems of the beauty parlor and there possible to give the better support to drive this beauty caring business it can be a havoc opportunity for the Bangladesh women to create heavy field of empowerment at equal portion development. (Bjerke, 2007 [23]; Birth, 1999\& 2001 [25]; Berard \& Brown, 1994 [25]) have suggested that females are more likely to start an enterprise for control over the quantity and quality of the work and as a way of coping with the "glass-ceiling".

\section{References}

[1] http://www.ijetmas.com/admin/resources/project/paper/f20150 4021427959493.pdf

[2] AK Yetisen, LR Volpatti, AF Coskun, S Cho, E Kamrani, H Butt, A Khademhosseini and SH Yun2015). Entrepreneurship." LabChip 15 (18):3638-60. doi:10.1039/c5lc00577a.PMID 26245815.

[3] http://pinchot.edu/

[4] http://www.dictionary.com/

[5] http://www.businessnewsdaily.com/2642entrepreneurship.html\#sthash.yXGRi8c7.dpuf

[6] http://www.yourarticlelibrary.com/entrepreneurship/womenentrepreneurs-concept-and-functions-of-womenentrepreneurs-explained/41096/

[7] http://www.oxforddictionaries.com/

[8] http://dictionary.cambridge.org/

[9] What is a marketing plan? definition and meaning." BusinessDictionary.com. Retrieved 2016-04-01.

[10] https://www.chapman.edu/business/_files/journals-andessays/jbm-editions/jbm-vol-16-01.pdf

[11] Gill, R. and Ganesh, S. (2007) "Empowerment, Constraint, and the Entrepreneurial Self: A Study of White Women Entrepreneurs", Journal of Applied Communication Research, 35 (3): 268-293.

[12] Haque, M, Itohara Y 2009, Women Empowerment through Participation in Micro- Credit Programme: A Case Study from Bangladesh, Journal Social Science, 5(3), pp. 244-250.

[13] Women Entrepreneurs in SMEs: Bangladesh Perspective MIDAS, November 2009, www.smef.org.bd/functions/dl_file.php

[14] http://www.dhakacourier.com.bd/

[15] World Bank, (2012), "Women Business and the Law: Removing barriers to economic inclusion", Published online, http://wbl.worldbank.org

[16] Shah, H. 2013. Creating an Enabling Environment for Women's Entrepreneurship in India. United Nations Economic and Social Commission for Asia and the Pacific (UN ESCAP), South and South-West Asia Office. South and South-West Asia Office. Development Papers 1304.

[17] IDLC monthly Business Review, Volume 10, Issue 7, 2014 http://www.idlc.com/business.../Monthly\%20Business\%20Re view\%20-\%20Jul.

[18] IDLC monthly Business Review, Volume 10, Issue 7, 2014/ http://www.idlc.com/business

[19] Storey, D. J. (2008), Understanding the Small Enterprise, London.

[20] Broehl, W. G. Jr. (1982), "Entrepreneurship in Less Developed Countries", Encyclopaedia of Entrepreneurship, Kent, C.A., Sexton, D. L., and Vesper, K. H., (eds.), Englewood Cliffs NJ: Prentice-Hall. 
[21] Comper, A. (1991), Women and Banking from Rhetoric to reality: In managing Changes through Global Networking, (ed), L. Heslop, Canadian Consortium of Management School.

[22] Gatewood, E. J., Carter, N. M., Brush, C. G. Greene, P. G. \& Hart, M. M. (2003), 'Women Entrepreneurs, Their ventures, and the Venture capital Industry: An Annotated Bibliography', Report 2003:1, ESBRI, Stockholm.

[23] Bjerke, B. (2007), 'Understanding Entrepreneurship' Edward Elgar, Cheltenham, UK.

[24] Birth, H. (1999), Barriers to Growth in Small Firms, Technology-3, Luleå University.

[25] Berard, J. and Brown, D. (1994), Services to Women Entrepreneurs: The Western Canadian Case. Manitoba Office, Western Economic Diversification Canada.

[26] http://www.bangladeshsociology.org/BEJS\%2011.2.pdf

[27] http://www.ijbhtnet.com/journals/Vol_4_No_3_May_2014/14. pdf

[28] Schumpeter, Joseph Alois (1934). The Theory of Economic Development: An Inquiry Into Profits, Capital, Credit, Interest, and the Business Cycle. Transaction Publishers. ISBN 978-0-87855-698-4.

[29] http://erangpurchitra.com/index.php?cdate=2016-04$18 \& \mathrm{pno}=\mathrm{p} 1$

[30] http://www.bwcci-bd.org/

[31] http://www.thedailystar.net/business

[32] http://www.rangpur.com/business-news.html

[33] http://www.rangpurchamber.com/web_baton/about_us_5.htm

[34] http://www.bdtradeinfo.com/yellowpages/des_data.php?subcat egory_id=164

[35] http://www.prothom-alo.com/

[36] http://blog.citigroup.com/2015/09/meet-fatema-khatun-bestwoman-entrepreneur-in-bangladesh
[37] http://bfwe.org/

[38] http://www.weab.org/

[39] http://asiafoundation.org/media/view/video/zLV1MTpC5qA/w omen-entrepreneurs-in-bangladesh

[40] http://www.adb.org/news/adb-provide-loans-smes-womenentrepreneurs-rural-bangladesh

[41] http://print.thefinancialexpress-bd.com/old/index.php?

[42] http://www.kuenselonline.com/new-economic-opportunitieswomens-entrepreneurship-in-the-hkh/

[43] https://en.wikipedia.org/wiki/Rangpur_Division

[44] http://www.ilo.org/global/about-theilo/newsroom/news/WCMS_234670/lang--en/index.htm

[45] https://en.wikipedia.org/wiki/Women_in_Bangladesh

[46] http://goextrem.blogspot.com/2009/05/social-problems-ofbangladesh.html

[47] http://www.irinnews.org/report/82575/bangladesh-womenmove-forward-challenges-remain

[48] http://www.indiacelebrating.com/essay/social-issues/womenempowerment/issues-and-problems-faced-by-women-in-india/

[49] http://www.bdresearch.org.bd/home/attachments/article/840/w omen\%20enterpreneurship.pdf

[50] https://www.linkedin.com/company/micro-industriesdevelopment-assistance-and-services-midas-

[51] https://www.linkedin.com/redirect?url=http\%3A\%2F\%2Fww $\mathrm{w} \% 2$ Emidas-bd\%2Ecom\&urlhash $=$ vuTM

[52] 'Bangladesh Women Chamber of Commerce and Industry In cooperation with The Center for International Private Enterprise Building Women in Business: A Situation Analysis of Women Entrepreneurism Bangladesh'(February, 2008). 